\title{
Intron-based genomic editing: a highly efficient method for generating knockin zebrafish
}

\author{
Jia $\mathrm{Li}^{1}$, Baibing Zhang ${ }^{1,3}$, Jiwen $\mathrm{Bu}^{1}$ and Jiulin $\mathrm{Du}^{1,2,3}$ \\ ${ }^{1}$ Institute of Neuroscience, State Key Laboratory of Neuroscience, CAS Center for Excellence in Brain Science, Shanghai \\ Institutes for Biological Sciences, Chinese Academy of Sciences, Shanghai 200031, China \\ ${ }^{2}$ School of Life Science and Technology, ShanghaiTech University, Shanghai 200031, China \\ ${ }^{3}$ University of Chinese Academy of Sciences, Shanghai 200031, China \\ Correspondence to: Jia Li, email: lijia@ion.ac.cn \\ Jiulin Du, email: forestdu@ion.ac.cn \\ Keywords: knockin, CRISPR/Cas9, zebrafish \\ Received: May 27, $2015 \quad$ Accepted: June 06, $2015 \quad$ Published: June 19, 2015 \\ This is an open-access article distributed under the terms of the Creative Commons Attribution License, which permits unrestricted use, \\ distribution, and reproduction in any medium, provided the original author and source are credited.
}

\section{ABSTRACT}

\begin{abstract}
The TALEN and CRISPR/Cas9 nuclease systems have been extensively utilized in genomic engineering of model organisms. In zebrafish, the nuclease systems have been successfully applied in generating loss-of-function knockout lines. However, genome-specific knockin techniques in zebrafish are still at the beginning. In this perspective, we briefly summarize the recent progresses on knockin approaches in zebrafish with a special focus on the newly developed intron-based knockin method.
\end{abstract}

Knockin animals are versatile tools for biological research [1]. For example, to understand the role of lethal genes in post-embryonic functions, it is usually to use knockin animals carrying LoxP insertions at interested genomic loci to generate conditional knockout animals [2]. Knockin-mediated fluorescent protein tagging of specific cells or endogenous proteins offers a powerful approach to track the dynamics of these cells or proteins in vivo [3]. For neuroscience research, knockin strategy can be used to make various animal tools for monitoring or manipulating the activity of specific types of neurons via cell type-specific expression of the calcium ion indicators GCaMPs, or the optogenetic elements channelrhodopsin-2 and halorhodopin, respectively [4].

Zebrafish (Danio rerio) is an emerging vertebrate animal model for life science. Although loss-of-function genomic editing for zebrafish mediated by zinc finger nucleases (ZFNs), transcription activator-like effector nucleases (TALENs), or the type II bacterial clustered regularly interspaced short palindromic repeats (CRISPR)/ CRISPR-associated (Cas) 9 system (CRISPR/Cas9) has been developed [5-9], knockin approach is still at the beginning. Lack of feasible knockin methods for inserting a large DNA sequence into specific genomic loci is becoming a bottleneck for zebrafish-relevant research.

Recently, we reported a newly established knockin method in Cell Research [10]. In this work, we took the advantage of the donor design used in homology-directed repair (HDR)-mediated knockin in mice and NHEJ (nonhomologous end joining)-mediated donor integration in cell cultures, and developed a CRISPR/Cas9-mediated efficient knockin strategy for zebrafish, which can be widely applied for labeling different cell types and tagging endogenous proteins. Using this method, we have specifically labelled dopaminergic neurons, serotoninergic neurons, glia cells and endothelial cells. And we have also succeeded in adding an EGFP tag to the C-terminal of endogenous glial fibrillary acidic protein [10].

Previously, although HDR-mediated knockin strategies were used to insert short DNA sequences and repair mutations in the zebrafish genome [11, 12], the insertion of a large DNA sequence (e.g., EGFP or Gal4) to a specific genome loci was still challenging. It was reported that the EGFP sequence was correctly integrated at the zebrafish tyrosine hydroxylase (th) locus through TALEN-mediated double-strand breaks (DSBs) and HDR, and the germline transmission efficiency was about $1.5 \%$ [13]. However, the targeted $t h$ gene was destroyed and the inserted EGFP failed to express [13] (Table 1).

NHEJ is at least 10 -fold more active than HR during early zebrafish development $[14,15]$. This is critically important, because the period from one-cell to embryonic stages, within which knockin integration takes place, is only several hours for zebrafish. The high efficiency of 
Table 1: Comparison between reported knockin methods in zebrafish.

\begin{tabular}{|c|c|c|c|c|c|c|c|c|}
\hline Lab & $\begin{array}{l}\text { integration } \\
\text { mechanism }\end{array}$ & $\begin{array}{l}\text { sgRNA } \\
\text { location }\end{array}$ & $\begin{array}{c}\text { donor } \\
\text { type }\end{array}$ & insertion & $\begin{array}{l}\text { mean rate } \\
\text { of germline } \\
\text { transmission }\end{array}$ & disadvantage & advantage & application \\
\hline $\begin{array}{c}\mathrm{Du} \\
\text { lab [10] }\end{array}$ & NHEJ & intron & plasmid & $\begin{array}{l}\text { Gal4/ } \\
\text { EGFP }\end{array}$ & $\sim 12 \%$ & $\begin{array}{l}\text { plasmid } \\
\text { backbone } \\
\text { insertion }\end{array}$ & $\begin{array}{l}\text { large fragment } \\
\text { insertion } \\
\text { endogenous } \\
\text { gene integrity } \\
\text { maintenance/ } \\
\text { high feasibility }\end{array}$ & $\begin{array}{l}\text { cell-type } \\
\text { specific } \\
\text { labeling / } \\
\text { endogens } \\
\text { protein } \\
\text { labeling }\end{array}$ \\
\hline $\begin{array}{l}\text { Ekker } \\
\text { lab [11] }\end{array}$ & HDR & exon & ssDNA & LoxP & $\sim 10 \%$ & $\begin{array}{l}\text { short fragment } \\
\text { insertion }\end{array}$ & LoxP knockin & $\begin{array}{l}\text { generation } \\
\text { of LoxP } \\
\text { knockin }\end{array}$ \\
\hline $\begin{array}{l}\text { Nusslein- } \\
\text { Volhard lab } \\
\text { [12] }\end{array}$ & HDR & exon & plasmid & $\begin{array}{l}\text { single } \\
\text { base }\end{array}$ & $\sim 11 \%$ & $\begin{array}{l}\text { short fragment } \\
\text { insertion }\end{array}$ & $\begin{array}{c}\text { Correction of } \\
\text { mismatches }\end{array}$ & $\begin{array}{l}\text { correction } \\
\text { of } \\
\text { mismatches }\end{array}$ \\
\hline $\begin{array}{c}\text { Zhang lab } \\
\text { [13] }\end{array}$ & HDR & exon & $\begin{array}{c}\text { Linearized } \\
\text { DNA }\end{array}$ & EGFP & $\sim 1.5 \%$ & $\begin{array}{l}\text { disruption of } \\
\text { endogenous } \\
\text { gene }\end{array}$ & $\begin{array}{c}\text { large fragment } \\
\text { insertion }\end{array}$ & $\begin{array}{l}\text { cell-type } \\
\text { specific } \\
\quad \text { labeling }\end{array}$ \\
\hline $\begin{array}{l}\text { Del Bene } \\
\text { lab }[16]\end{array}$ & NHEJ & exon & plasmid & Gal4 & $\sim 10 \%$ & $\begin{array}{l}\text { disruption of } \\
\text { endogenous } \\
\text { gene }\end{array}$ & $\begin{array}{l}\text { large fragment } \\
\text { insertion/easy } \\
\text { donor design }\end{array}$ & $\begin{array}{l}\text { cell-type } \\
\text { specific } \\
\quad \text { labeling }\end{array}$ \\
\hline $\begin{array}{l}\text { Higashijima } \\
\text { lab [17] }\end{array}$ & NHEJ & promoter & plasmid & $\begin{array}{l}\text { Gal4/ } \\
\text { RFP }\end{array}$ & $\sim 12 \%$ & $\begin{array}{l}\text { disruption of } \\
\text { promoter/ } \\
\text { plasmid } \\
\text { backbone } \\
\text { insertion }\end{array}$ & $\begin{array}{l}\text { large fragment } \\
\text { insertion/easy } \\
\text { donor design }\end{array}$ & $\begin{array}{l}\text { cell-type } \\
\text { specific } \\
\quad \text { labeling }\end{array}$ \\
\hline $\begin{array}{r}\text { Kawahara } \\
\text { lab [18] }\end{array}$ & NHEJ/HDR & exon & plasmid & EGFP & $\sim 15 \%$ & $\begin{array}{l}\text { disruption of } \\
\text { endogenous } \\
\text { gene }\end{array}$ & $\begin{array}{l}\text { large fragment } \\
\text { insertion/ } \\
\text { no plasmid } \\
\text { backbone } \\
\quad \text { insertion }\end{array}$ & \begin{tabular}{|l} 
cell-type \\
specific \\
labeling / \\
endogens \\
protein \\
$\quad$ labeling
\end{tabular} \\
\hline
\end{tabular}

NHEJ increases the rate of successful integration in such a short period. Therefore, NHEJ-based approaches should be in principle more suitable to be applied for donor integration. Meanwhile, unlike HR, NHEJ does not need the precise homology between the parent zebrafish and the targeting donor, avoiding time-consuming screening and genotyping of parent animals.

Two NHEJ-based knockin approaches were recently developed to insert the transcriptional transactivator Gal4 and EGFP into zebrafish genomic loci with high efficiency $[16,17]$. However, the integrity of targeted genes were disrupted as insertion events occurred within either the exon [16] or 5' Cis-regulatory elements of targeted genes [17]. As targeted genes themselves have biological functions, these strategies inevitably contaminate subsequent studies. To minimize indel mutations that introduced at junction sites in exons by the NHEJ mechanism, a recent study made use of a specially designed donor plasmid, which contains two GFP sgRNA target sequences and two 40-bp homologous sequences flanking sgRNA target locus in the genome [18]. When the GFP sgRNA and the genome-specific sgRNA were coinjected, the plasmid backbone is removed and the rest part of the donor is integrated into the targeted locus. The two 40-bp homology arm sequences enable the precise repair in the junction sites with an efficiency up to $79 \%$, probably through both NHEJ and HDR-involved mechanisms [18]. However, as the sgRNA target sequence must be excluded from the donor, the last 20-bp sequence in the targeted exon is missing in the integrated knockin genome, causing the deletion of the last several amino acids at the C-terminal and functional abnormality of the endogenous protein (Table 1).

In our knockin system, a sgRNA target is selected in an intron of targeted gene, and a DNA sequence spanning from the sgRNA target site to 3' intergenic region of targeted genes is added in a donor plasmid as the homologous arm (Figure 1). As this strategy retains 


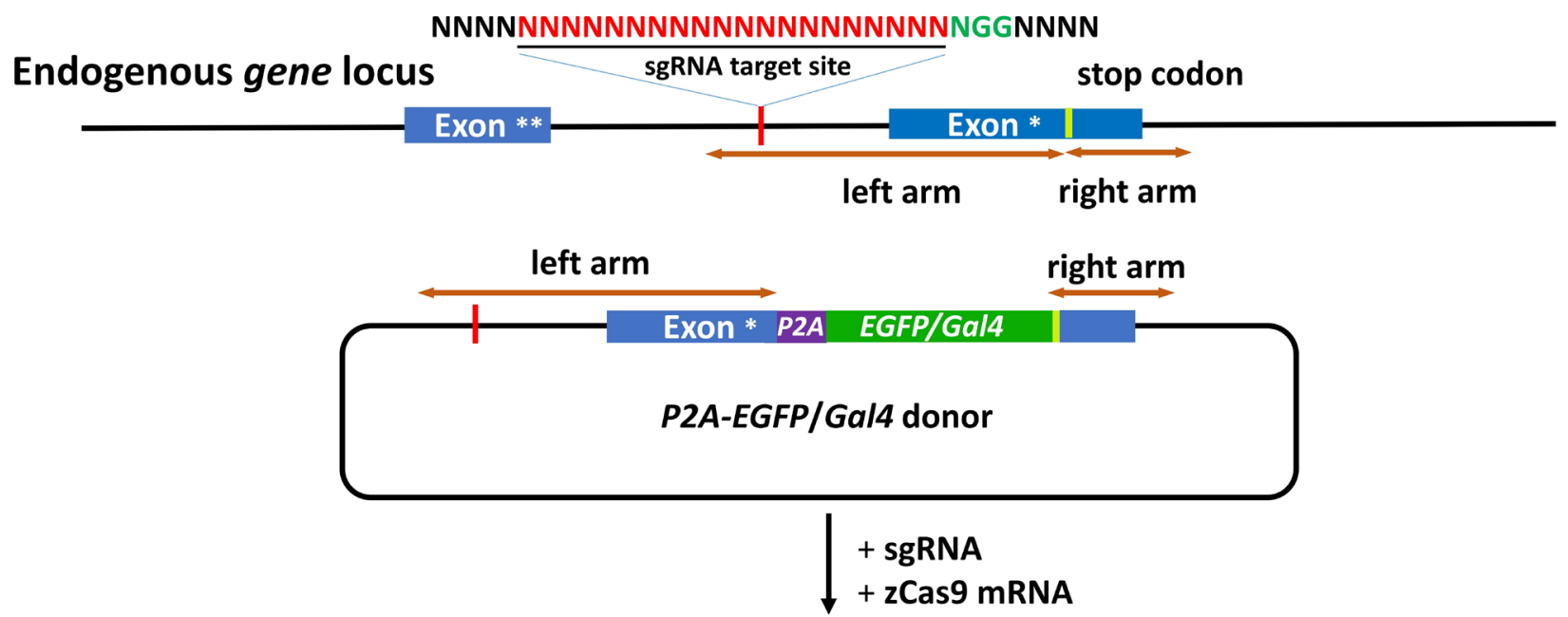

\section{Targeted gene locus}

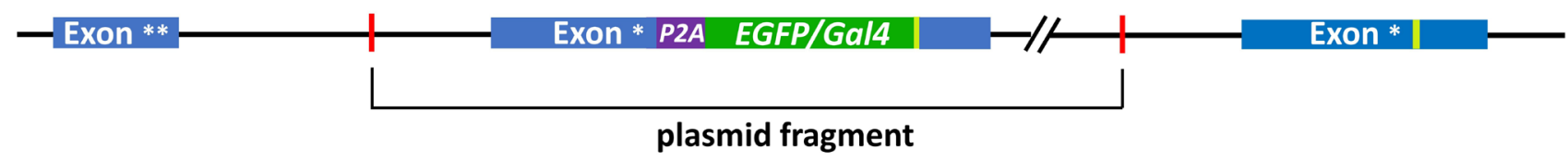

Figure 1: Schematic of the intron targeting-mediated strategy for generating $E G F P / G a l 4$ knockin at the zebrafish gene locus by using the CRISPR/Cas9 system. The sgRNA target sequence is showed in red and the protospacer adjacent motif (PAM) sequence in green. The P2A peptide is a linker for multicistronic expression. The left and right arm sequences of the donor plasmids are indicated by the brown lines with double arrows. The P2A-EGFP/Gal4 cassette was integrated into the endogenous gene locus after coinjection of the donor with the sgRNA and zCas9 mRNA. Exon ", the last exon. Exon ${ }^{* *}$, the penultimate exon.

the full reading frame and both the 5' and 3' regulatory elements of targeted endogenous genes, the integrity of targeted genes are maintained after predicted forward ligation of the donor into the targeted locus, which is verified by the western blot and the functional assays [10]. In addition, as the intron design of sgRNA targets can avoid imprecise integration in exons caused by NHEJ, and all insertion events are in-frame, our intron method results in a three-fold increase in the knockin efficiency in comparison with exon-based methods. The adding of the right arm in donor plasmid - the 3 ' intergenic region of targeted gene - is critically important. However, if a SV40 poly-A sequence rather than the 3 ' intergenic sequence of the endogenous gene is used, no fluorescence can be detected in th-P2A-EGFP knockin and gfap-P2A$E G F P$ knockin (unpublished data). This suggests that the endogenous 3' UTR in the knockin donor is critical for the expression of the targeted exogenous gene. For the donor construction, based on our experience, the length of arms does not matter, as long as the arm sequence meets the following requirements: 1) sgRNA must be included in the intron part of the left arm. 2) 3' intergenic region containing the full 3'UTR sequence of the mRNA must be included in the right arm. The other key point that guarantees successful knockin is the cleavage efficiency of the sgRNA. Several sgRNAs can be designed to target the intron sequence in the left arm, and the sgRNA with the highest cutting efficiency should be chosen to perform knockin experiment.

\section{OUTLOOK}

In the near future, the next-generation knockin approach should be developed for tagging endogenous proteins. As the expression level of some endogenous proteins may be very low, knockin of one or two copies of fluorescent proteins is still insufficient for observation of these proteins in vivo. Moreover, adding more copies of fluorescent sequences in the targeted gene will decrease the transcriptional and expressional efficiencies. To solve these problems, we may integrate the intron-based knockin with other methods, such as SNAP-tag system, antibodybased fluorescent amplification system, and drug-induced fluorescent system. Taking advantage of the transparency of zebrafish larvae and super-resolution imaging, intronbased knockin approach will definitely open up a new avenue for zebrafish-relevant research. 


\section{REFERENCES}

1. Capecchi MR. Gene targeting in mice: functional analysis of the mammalian genome for the twenty-first century. Nature reviews Genetics 2005; 6:507-512.

2. $\mathrm{Yu}$ Y, Bradley A. Engineering chromosomal rearrangements in mice. Nature reviews Genetics 2001; 2:780-790.

3. Zhang J, Campbell RE, Ting AY, Tsien RY. Creating new fluorescent probes for cell biology. Nature reviews Molecular cell biology 2002; 3:906-918.

4. Huang ZJ, Zeng H. Genetic approaches to neural circuits in the mouse. Annual review of neuroscience 2013; 36:183215.

5. Huang $\mathrm{P}$, Xiao A, Zhou M, Zhu Z, Lin S, Zhang B. Heritable gene targeting in zebrafish using customized TALENs. Nature biotechnology 2011; 29:699-700.

6. Doyon Y, Vo TD, Mendel MC, Greenberg SG, Wang J, Xia DF, Miller JC, Urnov FD, Gregory PD, Holmes MC. Enhancing zinc-finger-nuclease activity with improved obligate heterodimeric architectures. Nature methods 2011; 8:74-79.

7. Chang N, Sun C, Gao L, Zhu D, Xu X, Zhu X, Xiong JW, Xi JJ. Genome editing with RNA-guided Cas9 nuclease in zebrafish embryos. Cell research 2013; 23:465-472.

8. Hwang WY, Fu Y, Reyon D, Maeder ML, Tsai SQ, Sander JD, Peterson RT, Yeh JR, Joung JK. Efficient genome editing in zebrafish using a CRISPR-Cas system. Nature biotechnology 2013; 31:227-229.

9. Hruscha A, Krawitz P, Rechenberg A, Heinrich V, Hecht J, Haass C, Schmid B. Efficient CRISPR/Cas9 genome editing with low off-target effects in zebrafish. Development 2013; 140:4982-4987.

10. Li J, Zhang BB, Ren YG, Gu SY, Xiang YH, Huang C, $\mathrm{Du}$ JL. Intron targeting-mediated and endogenous gene integrity-maintaining knockin in zebrafish using the CRISPR/Cas9 system. Cell research 2015; 25:634-637.

11. Bedell VM, Wang Y, Campbell JM, Poshusta TL, Starker CG, Krug RG, 2nd, Tan W, Penheiter SG, Ma AC, Leung AY, Fahrenkrug SC, Carlson DF, Voytas DF, Clark KJ, Essner JJ, Ekker SC. In vivo genome editing using a highefficiency TALEN system. Nature 2012; 491:114-118.

12. Irion U, Krauss J, Nusslein-Volhard C. Precise and efficient genome editing in zebrafish using the CRISPR/Cas9 system. Development 2014; 141:4827-4830.

13. Zu Y, Tong X, Wang Z, Liu D, Pan R, Li Z, Hu Y, Luo Z, Huang P, Wu Q, Zhu Z, Zhang B, Lin S. TALEN-mediated precise genome modification by homologous recombination in zebrafish. Nature methods 2013; 10:329-331.

14. Dai J, Cui X, Zhu Z, Hu W. Non-homologous end joining plays a key role in transgene concatemer formation in transgenic zebrafish embryos. International journal of biological sciences 2010; 6:756-768.

15. Hagmann M, Bruggmann R, Xue L, Georgiev O, Schaffner W, Rungger D, Spaniol P, Gerster T. Homologous recombination and DNA-end joining reactions in zygotes and early embryos of zebrafish (Danio rerio) and Drosophila melanogaster. Biological chemistry 1998; 379:673-681.

16. Auer TO, Duroure K, De Cian A, Concordet JP, Del Bene F. Highly efficient CRISPR/Cas9-mediated knock-in in zebrafish by homology-independent DNA repair. Genome research 2014; 24:142-153.

17. Kimura Y, Hisano Y, Kawahara A, Higashijima S. Efficient generation of knock-in transgenic zebrafish carrying reporter/driver genes by CRISPR/Cas9-mediated genome engineering. Scientific reports 2014; 4:6545.

18. Hisano Y, Sakuma T, Nakade S, Ohga R, Ota S, Okamoto $\mathrm{H}$, Yamamoto T, Kawahara A. Precise in-frame integration of exogenous DNA mediated by CRISPR/Cas9 system in zebrafish. Scientific reports 2015; 5:8841. 